Proc. Estonian Acad. Sci. Geol., 1997, 46, 3, 119-126

\title{
REFLECTION OF WENLOCK OCEANIC EPISODES AND EVENTS ON THE CHITINOZOAN SUCCESSION OF ESTONIA
}

\author{
Viiu NESTOR
}

Institute of Geology, Estonia Blvd 7, EE-0001 Tallinn, Estonia

Received 21 May 1997, accepted 9 June 1997

\begin{abstract}
During this study the model of oceanic and climatic cyclicity by Jeppsson (J. Geol. Soc., $1990,147)$ was applied in the Wenlock sequence of Saaremaa on the basis of chitinozoan succession. The boundaries of some Wenlock episodes and events, established in the reference sections of Ireviken 3 and Vattenfallet outcrops, and Slitebrottet quarries of Gotland, were traced by chitinozoans in the Ohesaare section. In the paper the main changes in the chitinozoan assemblage during primo and secundo episodes and events are discussed. Diversity variations in primo and secundo episodes are expressed also in the monotonous marlstones of the Ohesaare core. The severest extinctions of the chitinozoan assemblage occurred during the Ireviken and Mulde events. The Boge and Valleviken events probably corresponded to an extensive stratigraphic gap in the sections of northern Saaremaa.
\end{abstract}

Key words: chitinozoans, Wenlock, oceanic episodes and events.

\section{INTRODUCTION}

A model for oceanic and climatic cyclicity, linked to the sedimentological and biotic fluctuations, was worked out by Jeppsson (1990). His main idea was to show alternation of primo and secundo episodes in oceanic state. Primo episodes were characterized by humid climate, cold bottom waters, reduction of carbonate deposition, and an increase in the clay content in sediments, related to the increased abundance and diversity of marine microplankton. Secundo episodes, on the contrary, were characterized by arid climate, salinity-dense oceanic bottom waters, sedimentation of pure carbonates in shallow waters, and rich and diverse benthic fauna. More or less abrupt changes between episodes, often leading to faunal extinctions, were termed as "events". Thirteen primo and secundo episodes and events are distinguished in the Wenlock sequence of Gotland, adopted as a reference sequence (Jeppsson et al., 1995; see Fig. 1). 


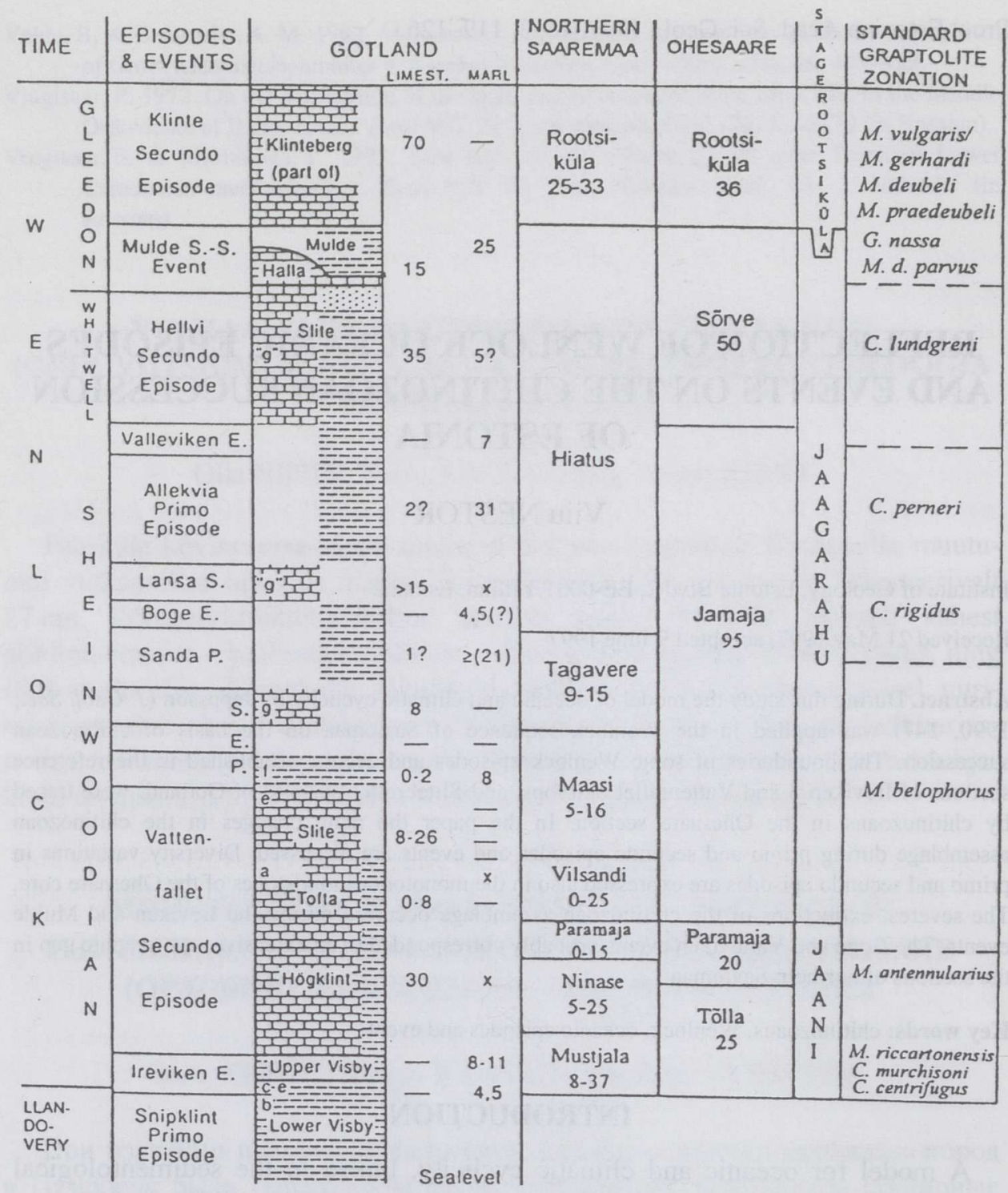

Fig. 1. Correlation of the Wenlock oceanic episodes and events of the Gotland reference sequence (from Jeppsson et al., 1995) with the regional stratigraphic units of Estonia. Stratigraphic thicknesses on Gotland are from Hede (1960) (cited in Jeppsson et al., 1995) and new measurements by Jeppsson: $\mathrm{x}$, presence proven but unmeasured; -, lack of strata, exposures or collections; S, Secundo Episode; P, Primo Episode; E, event. Figures given are the maxima for strata of each episode. Lithologies are indicated conventionally (i.e., blocks for limestone and dashes for argillaceous limestones). Stippling at the top of the Slite Beds represents the Slite siltstone. Graptolite biozones are from Jeppsson (1996). For northern Saaremaa the thickness range of stratigraphic units is shown. 

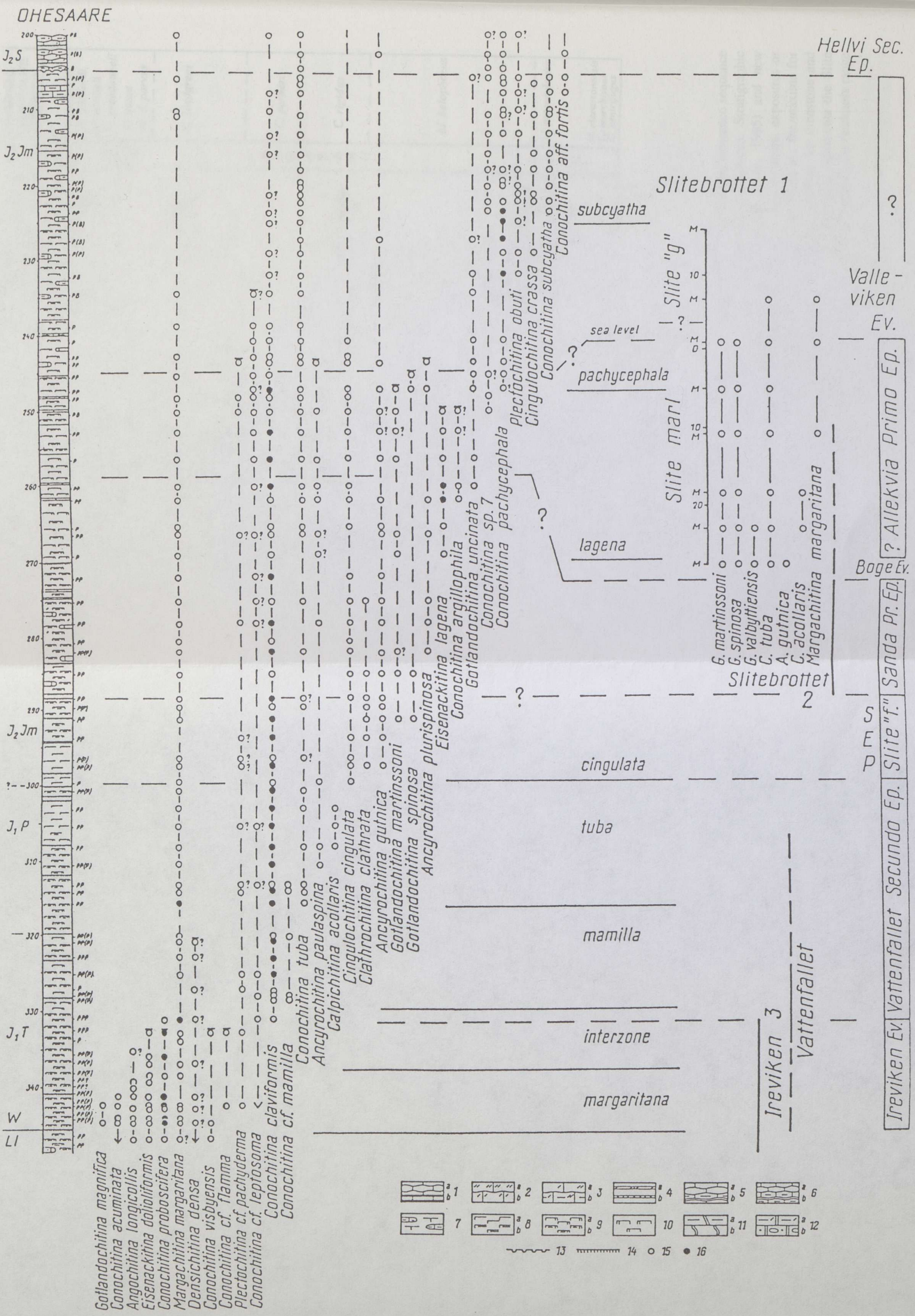

Fig. 2. Lithological log, ranges of selected chitinozoan species, succession of chitinozoan biozones, and span of the lower and middle Wenlock oceanic episodes and events in the section of the Ohesaare core. Stratigraphic position of the reference sections of the Ireviken 3 and Vattenfallet outcrops, and Slitebrottet quarries. Chiting Paramaja Member of Ep., Secundo Episode; P = Pr. Ep., Primo Episode; E = Ev., Event. Key to the lithological log: 1 , limestone: $a$, pure, $b$, limestone with marlstone interbeds; 2 , skeletal grainstone: $a$, coarse-grained, $b$, fine-grained; 3 , wackestone: $a$, pure, $b$, argillaceous; 4 , interbeds: $a$, skeletal grainstone, $b$, pelletal grainstone; 5 , nodular limestone: $a$, pure, $b$, argillaceous with marlstone interbeds; 6 , fine nodular limestone: $a$, pure, $b$, argillaceous with marlstone interbeds; 7 , marlstone nodular limestone: $a$, pure, $b$, argillaceous with limestone nodules; 8 , marlstone: $a$, calcareous, $b$, argillaceous; 9 , dolomitic marlstone: $a$, pure, $b$, argillaceous; 10 , calcitic dolomitic marl; 11 , dolomite: $a$, argillaceous, $b$, bioturbated; 12 , dolomite: $a$, argillaceous skeletal, $b$, bioclastic pelletal; 13 , hardground; 14 , metabentonite layer; 15 , occurrence
of species; 16 , abundant occurrence of species. Organic-walled microfossil association (the number of letters indicates the stage of prevalence): $\mathrm{P}$, planktic elements (mainly chitinozoans) prevailing; B, benthic elements prevailing. 
The boundaries of some Wenlock episodes and events were identified in the sections of Ireviken 3 and Vattenfallet outcrops, and Slitebrottet quarries (Jeppsson et al., 1995). As a result of recent investigation of these outcrops by a group of Estonian geologists, the corresponding intervals were established also in Estonian sections, including Ohesaare (Figs. 2, 3). The results will be published in a forthcoming paper by V. Nestor and R. Einasto. The correlation of the sections is based on chitinozoans only to show how different events and episodes reflect on the assemblage of chitinozoans. In the present paper they are not related to the conodont succession.

\section{RECOGNITION OF THE EPISODES AND EVENTS BY CHITINOZOANS}

The basal beds of the Wenlock are characterized by a rich assemblage of chitinozoans, dominated by Conochitina proboscifera. The Ireviken Event (Fig. 1) is expressed by a drastic decline of the chitinozoan species diversity in all studied early Wenlock sections of Estonia (Nestor, 1992, 1994). In the Ireviken reference section nine chitinozoan taxa disappeared finally from the Silurian sequence, whereas some taxa appeared in this interval. Ten chitinozoan datum levels have been established in the Ireviken 3 section. Stratigraphically the eighth level is the most important. It marks the extinction of Angochitina longicollis, which occurs in abundance throughout the upper Llandovery and basal Wenlock all over the world (Verniers et al., 1995). The Ireviken Event is represented in the lower part of the Mustjala Member and Tõlla Beds of the Jaani Regional Stage (Figs. 1, 2).

The reference section of the Vattenfallet Secundo Episode, succeeding the Ireviken Event, was fully studied by Laufeld (1979), we investigated only its lower part. According to Jeppsson et al. (1995), the Vattenfallet Secundo Episode began at the final extinction datum of the Ireviken Event below the boundary of the Högklint Beds at Vattenfallet. The interval of this secundo episode is characterized by a moderate species diversity in the reference section as well as in the Estonian sections studied (Nestor, 1994). This episode includes mainly transitional species of chitinozoans, dominated by Conochitina claviformis and Margachitina margaritana, together with Conochitina tuba and Calpichitina acollaris, which appear in the upper part of the interval (Fig. 2). In Estonian sections the Vattenfallet Secundo Episode embraces the uppermost part of the Mustjala Member and Tõlla Beds, also the Ninase and Paramaja members of the Jaani Stage (Figs. 1, 2). Jeppsson included in this episode also the lower units of the Slite Beds (units a, b, c, d, e), but correlation of this part of the sequence with Estonian sections is still uncertain. According to Laufeld (1974), Slite "a" and "b" contain only transitional species, in Slite "c" Conochitina tuba and Ancyrochitina gutnica make their appearance, in Slite "d" Clathrochitina clathrata appears. In Estonian sections Conochitina tuba occurs already in the 
upper part of the Jaani Stage, other species appear in the basal beds of the Jamaja Formation (Fig. 2), but Clathrochitina clathrata is present also in the Maasi Beds of the Jaagarahu Stage (Nestor \& Nestor, 1991). Therefore the lower units of the Slite Beds may partly be correlated with the Vilsandi(?) and Maasi beds of the Jaagarahu Stage, partly maybe with a stratigraphic gap, as was supposed by Jeppsson et al. (1994).

According to Jeppsson et al. (1995), the Sanda Primo Episode has not yet a precise lower boundary. Taking into consideration chitinozoan data, it would be better to include also Slite " $\mathrm{f}$ " in this episode. Slite "f" is characterized by a diverse assemblage of chitinozoans, including six species which appear in this interval for the first time (Laufeld, 1974). We have studied the Sanda Primo Episode in the lowermost $15 \mathrm{~m}$ of the reference section of Slitebrottet 2 quarry. The occurrence of Gotlandochitina martinssoni and $G$. spinosa, and the appearance of Eisenackitina lagena and Conochitina argillophila allows us to correlate this part of the section with the lower-middle part of the Jamaja Formation in the Ohesaare core (Fig. 2). During the Sanda Primo Episode, the most favourable conditions for chitinozoans existed in the area of the Sorrve Peninsula, where marly and argillaceous sediments of the Jamaja Formation deposited. In the northern part of Saaremaa, however, the coeval sediments are mostly represented by the dolomites and biomicritic limestones of the Tagavere Beds (Nestor \& Nestor, 1991) containing very few chitinozoans.

The part of the sequence corresponding to the Boge Event has not been investigated on chitinozoans at Slitebrottet, as it remains between the intervals studied by Laufeld (1974) in the Slitebrottet 1, and by us in the Slitebrottet 2 section. Possibly the disappearance of Eisenackitina lagena and Conochitina argillophila, not identified by Laufeld in the Slitebrottet 1 quarry, is connected with this event. The Boge Event is probably related to the beginning of an extensive stratigraphic gap between the Tagavere Beds of the Jaagarahu Stage and the Viita Beds of the Rootsiküla Stage in West Estonian sections (Nestor \& Nestor, 1991). In the Ohesaare section this level approximately coincides with the middle of the Jamaja Formation (Fig. 1).

The level of the next, Lansa Secundo Episode is still not determined by chitinozoans. According to Jeppsson et al. (1995) this interval is represented by pure limestones and it occurs also in the Slitebrottet 2 quarry, but evidently higher than the part of the section studied by us.

The reference section of the Allekvia Primo Episode is the Slitebrottet 1 quarry, from where chitinozoans were studied by Laufeld (1974). The similar assemblage of chitinozoans (see Fig. 2) and the disappearance of Gotlandochitina species (martinssoni, spinosa, valbyttiensis) in the topmost part of the section allow for rough correlation of this level with the corresponding level in the Ohesaare core. However, the interval of this episode is considerably smaller at Ohesaare than at Slitebrottet 1 (Fig. 2). 
The interval of the Valleviken Event terminates the Wenlock sequence in the Slitebrottet 1 quarry (Fig. 2). According to Laufeld (1974), this interval of the reef formation is not characterized by chitinozoans. Yet, they are present in the layer with Pentamerus gotlandicus, which was formed at the beginning of this event in other areas (Jeppsson et al., 1995). Conochitina pachycephala appears and five species of chitinozoans disappear during the Valleviken Event on Gotland as well as in the Ohesaare core (Fig. 2), approximately in the middleupper part of the Jamaja Formation of the Jaagarahu Stage. In some West Estonian sections (Kihnu and Häädemeeste) only the lower part of this interval is represented, followed by a stratigraphic gap (Nestor \& Nestor, 1991). The uppermost portion of about $40 \mathrm{~m}$ of the Jamaja Formation is characterized by a rich assemblage of chitinozoans (Plectochitina obuti, Cingulochitina crassa, Conochitina subcyatha, etc., see Fig. 2), not recorded from Gotland. Therefore, it is not excluded that on Gotland there exists an hiatus between the Valleviken Event and the Hellvi Secundo Episode (Fig. 2).

The beginning of the Hellvi Secundo Episode is characterized by a sudden decrease in the clay content in limestones. According to Jeppsson et al. (1995), this level coincides approximately with the lower boundary of the testis graptolite Biozone. These characteristics fit well with the beginning of the Sõrve Formation of the Jaagarahu Stage in the Ohesaare section (Kaljo, 1990). The episode shows a moderate occurrence of chitinozoans, dominated by Conochitina tuba and Conochitina cribrosa, the last species appearing in the upper part of the interval. The Hellvi Secundo Episode is represented in the lower part of the Sõrve Formation.

The beginning of the Mulde Event coincides with the uppermost part of the lundgreni graptolite Biozone (Jeppsson, 1996) and also with the end of the deposition of the Sorrve Formation (Fig. 3). The exact position of the boundary between the Hellvi Secundo Episode and the Mulde Event in the Ohesaare section is still unclear. There is one finding of Gothograptus nassa at a depth of $166.4 \mathrm{~m}$, which has conventionally been treated as the base of the nassa Biozone (Kaljo, 1990). A gradual extinction of most of the chitinozoan species, characteristic of the Wenlock, began already about $20 \mathrm{~m}$ below this level. Nine species disappear in the Mulde and Halla beds on Gotland (Laufeld, 1974) and 15 in the upper part of the Sorve Formation. Besides, there appear six species, including Sphaerochitina indecora, the index species of the highest chitinozoan biozone of the Wenlock.

The topmost, Klinte Secundo Episode, is not studied in the Ohesaare section as chitinozoans are very scarce in the skeletal pack- and wackestones of the lowermost part of the Rootsiküla Formation and totally missing in pelletal limestones and lagoonal dolomites of the rest of the same formation. According to Jeppsson et al. (1995), the lower boundary of the Klinte Secundo Episode is defined at the base of the Klinteberg Beds. To recognize this boundary in the Ohesaare section, conodont data should be used. Ozarkodina confluens densidentata 


\section{DHESAARE}

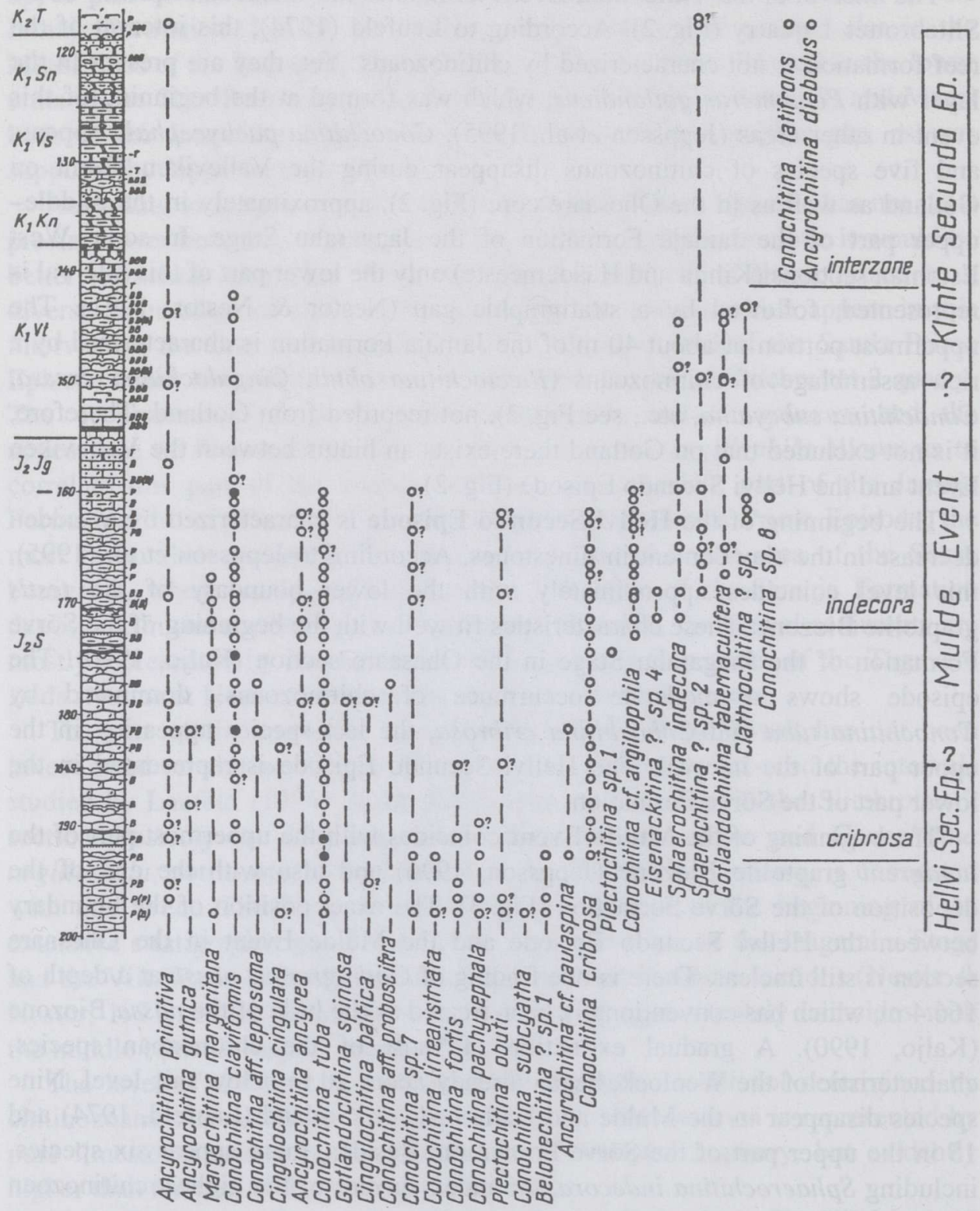

Fig. 3. Lithological log, ranges of chitinozoan species, succession of chitinozoan biozones, and span of the upper Wenlock oceanic episodes and events in the section of the Ohesaare core. Stratigraphic indices: $\mathrm{J}_{2} \mathrm{~S}$, Sõrve Formation of the Jaagarahu Stage; $\mathrm{J}_{2} \mathrm{Jg}$, Jaagarahu Formation of the same stage; $K_{1} V t$, Viita Beds of the Rootsiküla Stage; $K_{1} K n$, Kuusnõmme Beds of the Rootsiküla Stage; $K_{1} V s$, Vesiku Beds of the Rootsiküla Stage; $K_{1} S n$, Soeginina Beds of the Rootsiküla Stage; $\mathrm{K}_{2} \mathrm{~T}$, Torgu Formation of the Paadla Stage. Sec. Ep., Secundo Episode. Organicwalled microfossil association (the number of letters indicates the stage of prevalence): $\mathrm{P}$, planktic elements (mainly chitinozoans) prevailing; $\mathrm{B}$, benthic elements prevailing; $\mathrm{T}$, samples not containing organic-walled microfossils. Key to lithology see Fig. 2. 
Viira appears for the first time at the base of the Klinteberg Beds as well as in the Ohesaare section, at a depth of $149.8 \mathrm{~m}$ (Jeppsson et al., 1994). Therefore we may correlate the lower boundary of the Klinte Secundo Episode with the lowermost part of the Rootsiküla Stage (Fig. 3).

\section{CONCLUSIONS}

Jeppsson's model of primo and secundo oceanic episodes fits well with the diversity cycles of chitinozoans in the Wenlock succession of Estonia. The diversity and abundance of chitinozoans were higher during primo episodes, on average 9-10 species per sample, and lower during secundo episodes, 3-5 species per sample. Such diversity variations are observed also in deeper-water monotonous marlstones. Each event is characterized by a more or less abrupt decrease in chitinozoan diversity. The severest extinctions in the chitinozoan assemblage occurred during the Ireviken and Mulde events. The Boge and Valleviken events were probably coeval with the formation of extensive stratigraphic gaps in the upper part of the Jaagarahu Stage in the sections of northern Saaremaa.

\section{ACKNOWLEDGEMENTS}

I would like to thank B. Neuman from the Bergen University who guided us during geological field work on Gotland and L. Jeppsson for valuable advice concerning the Ireviken and Slitebrottet sections. I am also grateful to R. Einasto for lithological suggestions, $\mathrm{H}$. Nestor and other colleagues for critical remarks, and K. Ronk for technical help. The study was financially supported by the Estonian Science Foundation (grant 1665).

\section{REFERENCES}

Jeppsson, L. 1990. An oceanic model for lithological and faunal changes, tested on the Silurian record. J. Geol. Soc., 147, 663-674.

Jeppsson, L. 1996. Recognition of a probable secundo-primo event in the Early Silurian. Lethaia, 29, 311-315.

Jeppsson, L., Aldridge, R. J. \& Dorning, K. J. 1995. Wenlock (Silurian) oceanic episodes and events. J. Geol. Soc., 152, 487-498.

Jeppsson, L., Viira, V. \& Männik, P. 1994. Silurian conodont-based correlation between Gotland (Sweden) and Saaremaa (Estonia). Geol. Mag., 131, 201-218.

Kaljo, D. 1990. The Silurian of Estonia. In Field Meeting Estonia 1990. An Excursion Guidebook (Kaljo, D. \& Nestor, H., eds.). Estonian Academy of Sciences, Tallinn, 21-26.

Laufeld, S. 1974. Silurian Chitinozoa from Gotland. Fossils and Strata, 5, 1-130. 
Laufeld, S. 1979. Chitinozoans. In Lower Wenlock Faunal and Floral Dynamics - Vattenfallet Section, Gotland (Jaanusson, V., Laufeld, S. \& Skoglund, R., eds.). Sver. Geol. Unders., 73, 70-76.

Nestor, V. 1992. Chitinozoan diversity dynamics in the East Baltic Silurian. Proc. Estonian Acad. Sci. Geol., 41, 4, 215-224.

Nestor, V. 1994. Early Silurian Chitinozoans of Estonia and North Latvia. Academia. Vol. 4. Estonian Academy Publishers, Tallinn.

Nestor, V. \& Nestor, H. 1991. Dating of the Wenlock carbonate sequences in Estonia and stratigraphic breaks. Proc. Estonian Acad. Sci. Geol., 40, 2, 50-60.

Verniers, J., Nestor, V., Paris, F., Dufka, P., Sutherland, S. \& Van Grootel, G. 1995. A global Chitinozoa biozonation for the Silurian. Geol. Mag., 132, 6, 651-666.

\title{
WENLOCKI OOKEANI EPISOODIDE JA SÜNDMUSTE PEEGELDUMINE KITINOSOADE SUKTSESSIOONIS EESTIS
}

Viiu NESTOR

Kitinosoade järgnevuse alusel on võimalik rakendada Wenlocki ookeani ja kliima tsüklilisuse mudelit Saaremaa läbilõigete puhul. On määratud ligikaudsed tsüklitevahelised piirid ning analüüsitud muutusi kitinosoa kooslustes "primo" ja "secundo" episoodide ja sündmuste vältel. Liigilise mitmekesisuse tsüklilised muutused on täheldatavad ka Ohesaare Wenlocki läbilõike monotoonsetes merglites. Liikide suurim väljasuremine on seotud Irevikeni ja Mulde sündmusega Wenlocki alguses ja lõpus. Boge ja Vallevikeni sündmusele vastab tõenäoliselt ulatuslik stratigraafiline lünk Saaremaa kesk- ja põhjaosa läbilõigetes.

\section{ОТРАЖЕНИЕ ВЕНЛОКСКИХ ОКЕАНИЧЕСКИХ ЭПИЗОДОВ И СОБЫТИЙ НА СУКЦЕССИИ ХИТИНОЗОЙ В ЭСТОНИИ}

\author{
Вийу НЕСТОР
}

Использована модель океанической и климатической цикличности в венлоке о-ва Сааремаа, основанная на сукцессии хитинозой. По изменению ассоциаций хитинозой приблизительно определены границы между "примо" и “секундо" эпизодами и событиями. Выяснилось, что хитинозои более многочисленны и разнообразны в течение "примо" эпизодов. Различия видового разнообразия заметны и в толще монотонных мергелей венлока скв. Охесааре. Уровни максимального исчезновения видов связаны с Иревикским и Мульдеским событиями в начале и конце венлока. События Боге и Валлевикен совпадают, вероятно, с образованием значительного стратиграфического перерыва в разрезах северной и средней частей о-ва Сааремаа. 